\title{
Multi Drug Resistance Bacterial Isolates of Surgical Site Infection
}

\author{
Chandra Prakash Bhatt1 ${ }^{*}$, Rina Baidya ${ }^{2}$, Prakash Karki³, Rikesh Kumar Shah ${ }^{3}$, \\ Rashiak Miya3 ${ }^{3}$, Pratima Mahashate ${ }^{3}$, Kaushal Kishor Mishra ${ }^{3}$ \\ ${ }^{1}$ Kathmandu Medical College, Kathmandu, Nepal \\ ${ }^{2} \mathrm{~B}$ and $\mathrm{B}$ Hospital, Lalitpur, Nepal \\ ${ }^{3}$ Nobel College, Kathmandu, Nepal \\ Email: ${ }^{*}$ drcpbhatt@yahoo.com, ${ }^{*}$ drcpbhatt@gmail.com
}

Received 17 September 2014; revised 17 October 2014; accepted 10 November 2014

Copyright (C) 2014 by authors and Scientific Research Publishing Inc.

This work is licensed under the Creative Commons Attribution International License (CC BY).

http://creativecommons.org/licenses/by/4.0/

(c) ()

\begin{abstract}
Multi drug resistance microorganism is considered to be one of the major health problems. The aim of this study was to determine antibiotic susceptibility pattern of bacterial pathogens of surgical site infection. A total 250 samples were included, out of which $62.4 \%$ showed significant bacterial growth. Gram negative bacteria were $85.25 \%$ and gram positive bacteria were $14.75 \%$; among them $65.38 \%$ of the total isolates were multi drug resistance (MDR). The age group between 31 - 40 found the highest number of isolates $22.4 \%$. Among gram negative bacilli, the highest production of MDR was found in Acinetobacter spp. followed by Pseudomonas aeruginosa, Klebsiella pneumoniae and Escherichia coli. In gram positive cocci, the highest production of MDR was found in Staphylococcus aureus. Acinetobacter spp. was found highly susceptible to amikacin and gentamycin $20.1 \%$ followed by ofloxacin and ciprofloxacin $18.6 \%$ and $16.2 \%$ respectively. Staphylococcus aureus showed $100 \%$ sensitive to clindamycin whereas penicillin showed $100 \%$ resistance followed by amoxycillin $(93.75 \%)$. Amikacine and clindamycin were drugs of choice for gram negative and gram positive bacteria respectively. This study showed that alarming increase of infections was caused by multi drug resistance bacterial organisms. It increases length of stay and may produce lasting sequelae and requires extra resources for investigations, management and nursing care. Surveillance of surgical site infection is a useful tool to demonstrate the magnitude of the problem and find out appropriate preventive methods.
\end{abstract}

\section{Keywords}

Acinetobacter Spp., Bacterial Pathogens, Multi Drug Resistance (MDR)

\footnotetext{
${ }^{*}$ Corresponding author.
} 


\section{Introduction}

Microorganisms are important causes of morbidity in surgical patients. All surgical wounds are contaminated by both pathogens and body commensals [1] [2] but the development of infection in the site depends on complex interplay of many factors [3]. These may be microbial virulence [4]. Operation-related risk factors of patient including prolonged hospital stay before surgery, duration of the operation, tissue trauma, poor hemostasis, and foreign material in the wound, with these last greatly increasing the risk of serious infection despite a relatively small bacterial inoculum [5]. Meanwhile, the organisms that would invade the tissue depend on the location of the wound [6]. This is because of close correlations between microorganisms present in wounds in close proximity to those sites [7]. Superficial incisions are mostly colonized by endogenous bacterial flora (commensals) or pathogens, of which Staphylococcus aureus is frequently observed [8]. The microbial pathogens are therefore brought to wound site by direct contact, self-contamination and airborne [9]. Whichever organism(s) is involved depends on the locations of wound, exposure of the patients and the hospital hygiene. Selective pressure favouring resistant strains arises from misuse and over use of antibiotics [10]. MDR is one of the major threats due to widespread use of antimicrobial drugs in general population. It is a condition enabling a disease causing organism to resist distinct drugs or chemicals of a wide variety of structure and function targeted at eradicating the organism.

The widespread uses of antibiotics, together with the length of time during which they have been available have led to major problems of resistant organisms contributing to morbidity and mortality [11]. Despite technological advances in surgery, wound infection has been regarded as the most common nosocomial infection, especially in patients undergoing surgery [12]. Multi-drug resistant (MDR) bacteria are resistant to two or more classes of antimicrobial agents. Over the past decade, gram-positive bacteria, such as MRSA and VRE have attracted attention in the battle against MDR microorganisms. Paralleling the developments in gram-positive bacteria, infections caused by multi-drug resistant gram-negative bacilli (MDR-GNB) have become a growing problem. In recent years, bacterial resistance to different antibiotics has raised dramatically leaving physician with few therapeutic options. Methicillin resistant Staphylococcus aureus (MRSA), extended-spectrum- $\beta$-lactamases (ESBL) producing enterobacteria and vancomycin resistant enterococci (VRE) have become common hospital problems [13]. People infected with drug-resistant organisms are more likely to have longer and more expensive hospital stays, and may be more likely to die as a result of the infection. When the drug of choice for treating their infection doesn't work, they require treatment with second- or third-choice drugs that may be less effective, more toxic, and more expensive. This means that patients with an antimicrobial-resistant infection may suffer more and pay more for treatment. Surveys of the prevalence and antibacterial susceptibility patterns of bacterial isolates are important for determining appropriate empirical therapy for infections in critically-ill patients. The present study was carried out to determine drug resistance trends among pathogen of surgical site infection.

\section{Materials and Methods}

\subsection{Setting}

A prospective study was conducted at B and B Hospital, Gwarko, Lalitpur during July 2012 to December 2012. In this study 250 samples from surgical sites infection were collected from the patients visiting B and B Hospital for culture and antibiotic susceptibility testing, and were processed according to the standard laboratory methods. The research objective and methods were explained to the patients and informed consent was taken from each participant before collection of specimen.

\subsection{Specimens}

Purulent material and wound swab were collected and sent to the microbiology section of Pathology Department, B and B Hospital. Strict aseptic condition was maintained during collection and processing of the samples to maintain quality control. Two swabs were collected.

\subsection{Isolation and Identification of Bacterial Organisms}

Purulent material and wound swab specimens were inoculated directly or with the help of sterile inoculating 
loop onto MacConkey agar and blood agar medium by continuous streaking method and incubated at $37^{\circ} \mathrm{C}$ for 24 hours in aerobic condition. The identification of bacterial isolates, found significant growth was done by standard microbiological techniques as described in Bergey's Manual [14] of systemic bacteriology which comprises of studying the colony characters, staining reactions and biochemical tests. The sterility of each batch of test medium was confirmed by incubating one un-inoculated tube and plate along with inoculated ones as quality control. The quality of media were assured by testing each batch of medium using control strains of bacteria known to give positive and negative reactions.

\subsection{Antibiotic Susceptibility Test}

Antibiotic susceptibility of the isolates was determined by Kirby Bauer disc diffusion method, according to CLSI recommendations [15]. Antibiotic discs (Hi Media) was used for gram positive isolates were ciprofloxacin (5 mcg), amoxicillin (20 mcg), erythromycin (15 mcg), clindamycin (2 mcg), gentamycin (10 mcg), cloxacillin (1 mcg), and penicillin (10 units), For gram negative isolates ciprofloxacin (5 mcg), ofloxacin (5 mcg), ceftriaxone (30 mcg), gentamycin (10 mcg), chloramphenicol (30 mcg), amikacin (30 mcg), were tested. The zones of inhibition were measured and the organisms identified as sensitive or resistant based on standard criteria. Control strains were used for checking the quality of discs and reagents. The results are expressed in percentage. Data was analysed by EPI-Info and presented by chart and diagrams.

\section{Results}

Total 250 clinical samples were included in this study out of that 156 (62.4\%) were bacterial culture positive (Table 1). Nine different bacterial species were isolated; among them 133 were gram negative and 23 were gram positive. Multi drug resistance (MDR) was found to be $65.38 \%$. Acinetobacter spp. was the most predominant isolates (32.33\%) followed by Pseudomonas aeruginosa (21.80\%), Klebsiella pneumoniae (17.29\%), Escherichia coli (16.55\%), and Enterobacter spp. (9.78\%), whereas Staphylococcus aureus (69.57\%), and CoNS (13.05\%) were the major gram positive isolates (Table 2). The age group 31 - 40 years had the maximum

Table 1. Growth profile of surgical samples.

\begin{tabular}{cccc}
\hline S.N & Growth & No. of samples & $\%$ \\
\hline 1. & Culture positive & 156 & 62.4 \\
2. & No growth & 94 & 37.6 \\
& Total & 250 & 100 \\
\hline
\end{tabular}

Table 2. Distribution of bacterial organisms in different pathological specimens.

\begin{tabular}{|c|c|c|c|c|}
\hline Pathogens & Number & Percentage & MDR Number & Percentage \\
\hline Gram negative & 133 & 85.25 & 89 & 57.0 \\
\hline Acinetobacter spp. & 43 & 32.33 & 36 & 23.0 \\
\hline Pseudomonas aeruginosa & 29 & 21.80 & 16 & 10.25 \\
\hline Klebsiella pneumoniae & 23 & 17.29 & 16 & 10.25 \\
\hline Escherichia coli & 22 & 16.55 & 12 & 7.6 \\
\hline Enterobacter spp. & 13 & 9.78 & 8 & 5.1 \\
\hline Proteus mirabilis & 3 & 2.25 & 1 & 0.64 \\
\hline Gram positive & 23 & 14.75 & 13 & 8.3 \\
\hline Staphylococcus aureus & 16 & 69.57 & 11 & 7.05 \\
\hline Coagulase negative staphylococci (CoNS) & 3 & 13.05 & 1 & 0.64 \\
\hline Enterococcus spp. & 2 & 8.69 & 1 & 0.64 \\
\hline Streptococcus spp. & 2 & 8.69 & 0 & 00 \\
\hline Total & 156 & 100 & 102 & 65.3 \\
\hline
\end{tabular}


growth 35 (22.4\%) followed by 41 - 50 years age group 27 (17.3\%) and 21 - 30 years age group 21 (13.4\%) respectively (Table 3). Acinetobacter spp. was found highly susceptible to amikacin and gentamycin 9 (20.1\%) followed by ofloxacin and ciprofloxacin 8 (18.6\%) and 7 (16.2\%) respectively. Amikacin (58.62\%) was the most effective antibiotics against Pseudomonas aeruginosa followed by chloramphenicol, ofloxacin and gentamycin (44.82\%). Klebsiella pneumoniae, amikacin was found (56.52\%) susceptible whereas ceftriaxone showed (82.60\%) resistance followed by ciprofloxacin (73.91\%). Escherichia coli, the most susceptible antibiotics was amikacin (83.36\%) followed by gentamycin (63.63\%) and the most resistant antibiotics were ceftriaxone (63.63\%) followed by ciprofloxacin and ofloxacin (54.54\%) (Table 4). Antibiotics susceptibility pattern of Staphylococcus aureus, clindamycin showed $100 \%$ susceptible whereas penicillin showed $100 \%$ resistance followed by amoxycillin (93.75\%). In case of CoNS. ciprofloxacin and clindamycin was $66.66 \%$ susceptible whereas amoxcillin and erythromycin were $100 \%$ resistance (Table 5).

\section{Discussion}

The problem of infection has been persistent in the surgical world even after the introduction of antibiotics. Pathogens that infect surgical wounds can be part of normal flora or acquired from the hospital environment or other infected patients. S. aureus, being the normal microbial flora of the skin is one of the commonest causes of wound infection. The countries where resources are limited, postoperative surgical site infections remain as one of the major types of nosocomial infections [16]. The successful management of patients suffering from bacterial illnesses depends upon the identification of the types of organisms that cause the diseases and the selection of an effective antibiotic against the organism. Antibiotics are one of the pillars of modern medical care and play a major role in prophylaxis and treatment of infectious diseases. Cognizant of this, the issue of their availability, selection and proper use are of critically important to the global community [13]. Wound infections have been a

Table 3. Distribution of pathogens according to age of the patients.

\begin{tabular}{rcccccccc} 
Age & $\begin{array}{c}0-10 \\
\text { years }\end{array}$ & $\begin{array}{c}11-20 \\
\text { years }\end{array}$ & $\begin{array}{c}21-30 \\
\text { years }\end{array}$ & $\begin{array}{c}31-40 \\
\text { years }\end{array}$ & $\begin{array}{c}41-50 \\
\text { years }\end{array}$ & $\begin{array}{c}51-60 \\
\text { years }\end{array}$ & $\begin{array}{c}61-70 \\
\text { years }\end{array}$ & $\begin{array}{c}71-80 \\
\text { years }\end{array}$ \\
$\begin{array}{l}\text { Total no. } \\
\text { of isolates }\end{array}$ & 8 & 12 & 21 & 35 & 27 & 13 & 15 & 14 \\
\hline
\end{tabular}

Table 4. Antibiotic resistant pattern of gram negative bacteria.

\begin{tabular}{|c|c|c|c|c|c|c|}
\hline Antibiotics & $\begin{array}{l}\text { Acinetobacter } \\
\text { spp. }(\mathrm{N}=43)\end{array}$ & $\begin{array}{c}\text { Pseudomonas } \\
\text { aeruginosa }(\mathrm{N}=29)\end{array}$ & $\begin{array}{c}\text { Klebsiella } \\
\text { pneumoniae }(\mathrm{N}=23)\end{array}$ & $\begin{array}{l}\text { Escherichia } \\
\text { coli }(\mathrm{N}=22)\end{array}$ & $\begin{array}{l}\text { Enterobacter } \\
\text { spp. }(\mathrm{N}=13)\end{array}$ & $\begin{array}{c}\text { Proteus } \\
\text { mirabilis }(\mathrm{N}=3)\end{array}$ \\
\hline Ciprofloxacin & 36 & 18 & 17 & 12 & 8 & 1 \\
\hline Ofloxacin & 35 & 16 & 15 & 12 & 8 & 1 \\
\hline Ceftriaxone & 37 & 26 & 19 & 14 & 10 & 1 \\
\hline Gentamycin & 34 & 16 & 15 & 8 & 8 & 2 \\
\hline Amikacin & 34 & 12 & 10 & 3 & 5 & 0 \\
\hline Chloramphenicol & 40 & 16 & 15 & 7 & 7 & 2 \\
\hline
\end{tabular}

Table 5. Antibiotic resistant pattern of gram positive bacteria.

\begin{tabular}{|c|c|c|c|c|}
\hline Antibiotics & Staphylococcus aureus $(\mathrm{N}=16)$ & CoNS $(\mathrm{N}=3)$ & Enterococcus spp. $(\mathrm{N}=2)$ & Streptococcus spp. $(\mathrm{N}=2)$ \\
\hline Ciprofloxacin & 12 & 1 & 1 & 0 \\
\hline Gentamycin & 10 & 0 & 2 & 0 \\
\hline Amoxycillin & 15 & 3 & 2 & 0 \\
\hline Erythromycin & 8 & 3 & 2 & 0 \\
\hline Clindamycin & 0 & 1 & 0 & 0 \\
\hline Cloxacillin & 2 & 1 & 0 & 0 \\
\hline Penicillin & 16 & 0 & 1 & 1 \\
\hline
\end{tabular}


problem in the field of surgery for a long time. Advances in control of infections have not completely eradicated this problem because of development of drug resistance. Antimicrobial resistance can increase complications and costs associated with procedures and treatment.

In this study total 250 clinical samples were included out of that 156 (62.4\%) samples showed culture positive among them 133 (85.25\%) were gram negative bacilli and 23 (14.75\%) were gram positive cocci. Similar study conducted by Olowe et al. [17] reported that rate of bacterial isolate among clinically septic wound infections was $85.7 \%$, out of that $61.4 \%$ of the isolates were gram negative bacteria and $38.6 \%$ of the isolated were gram positive cocci. Raza et al. [18] showed that 96/120 (80\%) sample was culture positive out of them 58.33\% were gram negative bacilli.

Surgical wound infection was most prevalent in the age group of 31 - 40 years 33 (22.4\%) followed by 41 50 years age group 27 (17.5\%) and 21 - 30 years age group 21 (13.4\%).

Altogether 9 different bacterial species were isolated, in which 6 species were gram negative and 3 species were gram positive. Among gram negative, Acinetobacter spp. (32.33\%) was the most prevalent pathogens followed by Pseudomonas aeruginosa (21.80\%), Klebsiella pneumoniae (17.29\%), and Escherichia coli (16.55\%). whereas in gram positive, S. aureus (69.57\%) was common clinical pathogens followed by CoNS (13.05\%). Raza et al. [18] reported that most frequently isolated organisms were S. aureus (41.67\%) followed by E. coli (25\%), and Klebsiella pneumoniae (10.4\%).

This study showed that $S$. aureus was the major gram positive cocci (69.57\%) associated with surgical wound infections. This result is consistent with data in Eastern Nigeria [19]. According to CDC, Staphylococcus aureus is the most prevalent organism associated with surgical wound infections. Majority of the Staphylococci were multiple antibiotics resistant and these multi-drug resistance patterns had been documented already [20]. This may reflect the degree of carriage of $S$. aureus as a member of the skin flora of the patients as well as nasal carriage by the Surgeons and other Health Workers. This calls for periodic screening of members of the surgical team for nasal carriage of $S$. aureus and their prompt treatment before any operative measures.

Among gram negative isolates, Acinetobacter spp., Klebsiella pneumoniae, Escherichia coli, and Pseudomonas aeruginosa demonstrated high level of resistance to most of the antibiotics tested. This finding was also in agreement with the findings of other studies [20] [21]. The ability to persist on inanimate dry surfaces (humidifiers, hospital equipments, furniture, mattresses) and animate (human skin and mucus membranes) objects is probably a main factor in the long-term existence of particular Acinetobacter spp. in the hospital setting which subsequently results in a prolonged opportunity to infect patients. However, although $A$. baumannii is the most prevalent Acinetobacter species in clinical samples, it is not the most prevalent Acinetobacter species in the hospital environment.

Out of 156 culture positive samples, 102 isolates (65.38\%) were found to be MDR. In gram negative isolates, $66.9 \%$ (89/133) were found MDR whereas in gram positive isolates, 56.52\% (13/23) were found MDR. This result was also in agreement with the finding of other studies [20] [21]. Similar result were reported by Raza et al. [18] $66.7 \%$ of bacterial isolates showed multi drug resistance whereases $83.33 \%$ (45/54) were gram negative bacteria and $47.5 \%$ (19/40) gram positive isolates were MDR. Multiple drug resistance (MDR) is defined as resistance of two groups of the antimicrobial agents. The high frequency of multiple antibiotics resistance might be a reflection of inappropriate use of antimicrobials, lack of laboratory diagnostic tests, unavailability of guideline for the selection of antibiotics. Outbreaks of $S$. aureus resistant to beta-lactam antibiotics have been frequently associated with devastating nosocomial infections [22]-[24]. Bacterial resistance to beta-lactam antibiotics is primarily due to the production of beta-lactam ring of the antibiotics rendering them inactive [25]. Inappropriate practices like misuse and abuse of antibiotics and unskilled practitioners can also lead to emergence of resistance in bacteria. Expired antibiotics, self medication, counterfeit drugs, inadequate hospital control measures can as well promote the development of resistance in clinical isolates [24]. The worldwide escalation in both community- and hospital-acquired antimicrobial-resistant bacteria is threatening the ability to effectively treat patients, emphasizing the need for continued surveillance, more appropriate antimicrobial prescription, prudent infection control and new treatment alternatives [20] [24]. The use of molecular biology techniques would also enhance the molecular identification of resistance genes [24].

\section{Conclusion}

Present study shows that out of 250 clinical samples, 156 showing culture positive among them (65.38\%) is 
found to be multi drug resistant (MDR). In gram negative isolates, 66.9\% (89/133) were found MDR whereas in gram positive isolates, 56.52\% (13/23) were found MDR. Amikacin and clindamycin were drugs of choice for gram negative and gram positive bacterial isolates respectively. Unfortunately the emergence of antibiotic resistance bacteria is threatening the effectiveness of many antimicrobial agents which has increased the hospital stay and may produce lasting sequelae and requires extra resources for investigations, management and nursing care. Surveillance of surgical sit infection is a useful tool to demonstrate the magnitude of the problem and find out appropriate preventive methods.

\section{Acknowledgements}

The authors are thankful to all the doctors, nursing staffs and technicians of the hospital for their support and help during this study.

\section{References}

[1] Davis, N., Curry, A., Gambhir, A.K., Panigrahi, H. and Walker, C.R.C. (1999) Intraoperative Bacterial Contamination in Operations for Joint Replacement. Journal of Bone and Joint Surgery, 81, 886-889.

[2] Anguzu, J. and Olila, D. (2007) Drug Sensitivity Patterns of Bacterial Isolates from Septic Post-Operative Wounds in a Regional Referral Hospital in Uganda. African Health Sciences, 7, 148-154.

[3] Olsen, M.A., Nepple, J.J. and Riew, K.D. (2008) Risk Factors for Surgical Site Infection Following Orthopaedic Spinal Operations. Journal of Bone and Joint Surgery (American), 90, 62-69. http://dx.doi.org/10.2106/JBJS.F.01515

[4] Bowler, P.G., Duerden, B.I. and Armstrong, D.G. (2001) Wound Microbiology and Associated Approaches to Wound Management. Clinical Microbiology Reviews, 14, 244-269. http://dx.doi.org/10.1128/CMR.14.2.244-269.2001

[5] Howard, R.J. and Lee Jr., J.T. (1995) Surgical Wound Infections: Epidemiology, Surveillance, and Clinical Management. In: Howard, R.J. and Simmons, R.L, Eds., Surgical Infectious Diseases, 3rd Edition. Allyn and Bacon, East Norwalk CT, 401-412.

[6] Oluwatosin, O.M. (2005) Surgical Wound Infection: A General Overview. Annals of Ibadan Postgraduate Medicine, 3, 26-31.

[7] Brook, I. (1987) Microbiology of Human and Animal Bite Wounds in Children. Pediatric Infectious Disease Journal, 6, 29-32. http://dx.doi.org/10.1097/00006454-198701000-00008

[8] Lilani, S.P., Jangale, N., Chowdhary, A. and Daver, G.B. (2005) Surgical Infection in Clean and Clean-Contaminated Cases. Indian Journal of Medical Microbiology, 23, 249-252.

[9] Prakash, K.S. (2010) Nosocomial Infection: General Overview. www.delhimedicalcouncil.nic.in/nosocomialinfections.pdf

[10] Thomson, K.S.C.C. and Sanders, E.S. (1999) Moland. Antimicrobial Agents and Chemotherapy, 43, $1393-1400$.

[11] Elmer, W.K., Stephen, D.A., William, M.J., Schreckenberger, P.C. and Winn, W.C. (1997) Antimicrobial Susceptibility Testing. In: Colour Atlas and Textbook of Diagnostic Microbiology, 5th Edition, Raven Publisher, Philadelphia, 69-120.

[12] Dionigi, R., Rovera, F., Dionigi, G., Imperatori, A., Ferrari, A., Dionigi, P. and Dominioni, L. (2001) Risk Factors in Surgery. Journal of Chemotherapy, 13, 6-11. http://dx.doi.org/10.1179/joc.2001.13.Supplement-2.6

[13] Brooks, G.F., Butel, J.S. and Morse, S.A. (2004) Jawetz, Melnick and Adelberg's Medical Microbiology. 23rd Edition, McGraw Hill, New York.

[14] Geoge, M.D., David, R.B. and Richard, W.C. (2001) Bergey’s Manual of Systemic Bacteriology. 2nd Edition, Springer, New York.

[15] Clinical and Laboratory Standards Institute (2013) Performance Standards for Antimicrobial Susceptibility Testing. Twenty-Third Information Supplement (M100-S23). Clinical and Laboratory Standards Institute, Wayne.

[16] Probhakar, P., Roje, D., Castle, D., Rat, B., Fletcher, P., Duquesnay, D., Venugopal, S. and Carpenter, R. (1983) Nosocomial Surgical Infections: Incidence and Cost in a Developing Country. American Journal of Infection Control, 11, 51-56. http://dx.doi.org/10.1016/0196-6553(83)90099-8

[17] Olowe, O.A., Titilolu, F.T., Bisi-Johnson, M.A. and Mosanya, J.T. (2014) Antibiogram of Surgical Site Infection in a Tertiary Health Care Facility in Osogbo, South Western Nigeria. Current Trends in Technology and Science, 3.

[18] Raza, M.S., Chander, A. and Ranabhat, A. (2013) Antimicrobial Susceptibility Patterns of the Bacterial Isolates in Post-Operative Wound Infections in a Tertiary Care Hospital, Kathmandu, Nepal. Open Journal of Medical Microbiology, 3, 159-163. 
[19] Nwachukwu, N.C., Orji, F.A. and Okike, U.M. (2009) Antibiotic Susceptibility Patterns of Bacterial Isolates from Surgical Wounds in Abia State University Teaching Hospital, Abia-Nigeria. Research Journal of Medicine and Medical Sciences, 4, 575-579.

[20] Mulu, A., Moges, F., Tesema, B. and Kassu, A. (2006) Patterns and Multiple Drug Resistance of Bacterial Pathogens at University of Gondar Teaching Hospital, Northwest Ethiopia. Ethiopian Medical Journal, 44, 125-131.

[21] Biadglegne, F., Abera, B., Alem, A. and Anagaw, B. (2009) Bacterial Isolates from Wound Infection and Their Antimicrobial Susceptibility Pattern in Felege Hiwot Referral Hospital, Northwest Ethiopia. Ethiopian Journal of Health Sciences, 19, 173-177.

[22] Depardieu, F., Podglajen, I., Leclercq, R., Collatz, E. and Courvalin, P. (2007) Modes and Modulations of Antibiotic Resistance Gene Expression. Clinical Microbiology Reviews, 20, 79-114. http://dx.doi.org/10.1128/CMR.00015-06

[23] Buhlmann, M., Bogli-Stuber, K., Droz, S. and Muhlemann, K. (2008) Rapid Screening for Carriage of MethicillinResistant Staphylococcus aureus by PCR and Associated Costs. Journal of Clinical Microbiology, 46, 2151-2154. http://dx.doi.org/10.1128/JCM.01957-07

[24] Chikere, C.B., Chikere, B.O. and Omoni, V.T. (2008) Antibiogram of Clinical Isolates from a Hospital in Nigeria. African Journal of Biotechnology, 7, 4359-4363.

[25] Akpan, U.E. (1992) Antibiotic Usage: A Need for an Antibiotic Policy in Nigeria. Pharmacy World Journal, $19,42-44$. 
Scientific Research Publishing (SCIRP) is one of the largest Open Access journal publishers. It is currently publishing more than 200 open access, online, peer-reviewed journals covering a wide range of academic disciplines. SCIRP serves the worldwide academic communities and contributes to the progress and application of science with its publication.

Other selected journals from SCIRP are listed as below. Submit your manuscript to us via either submit@scirp.org or Online Submission Portal.
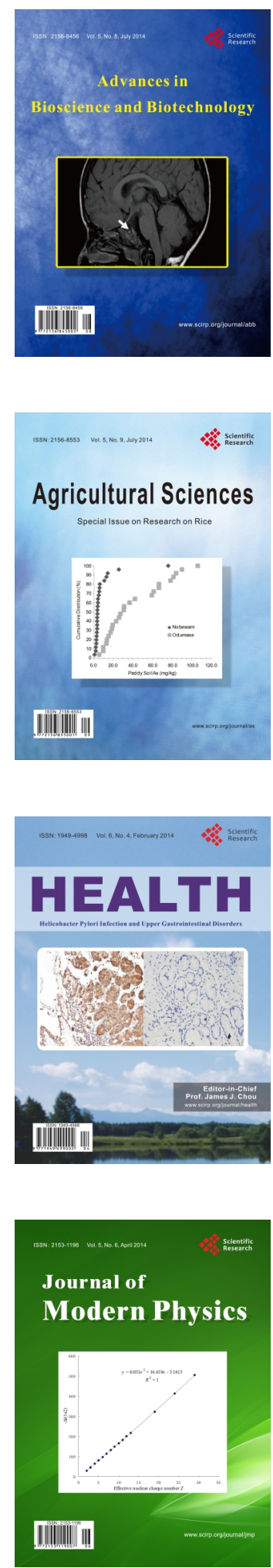
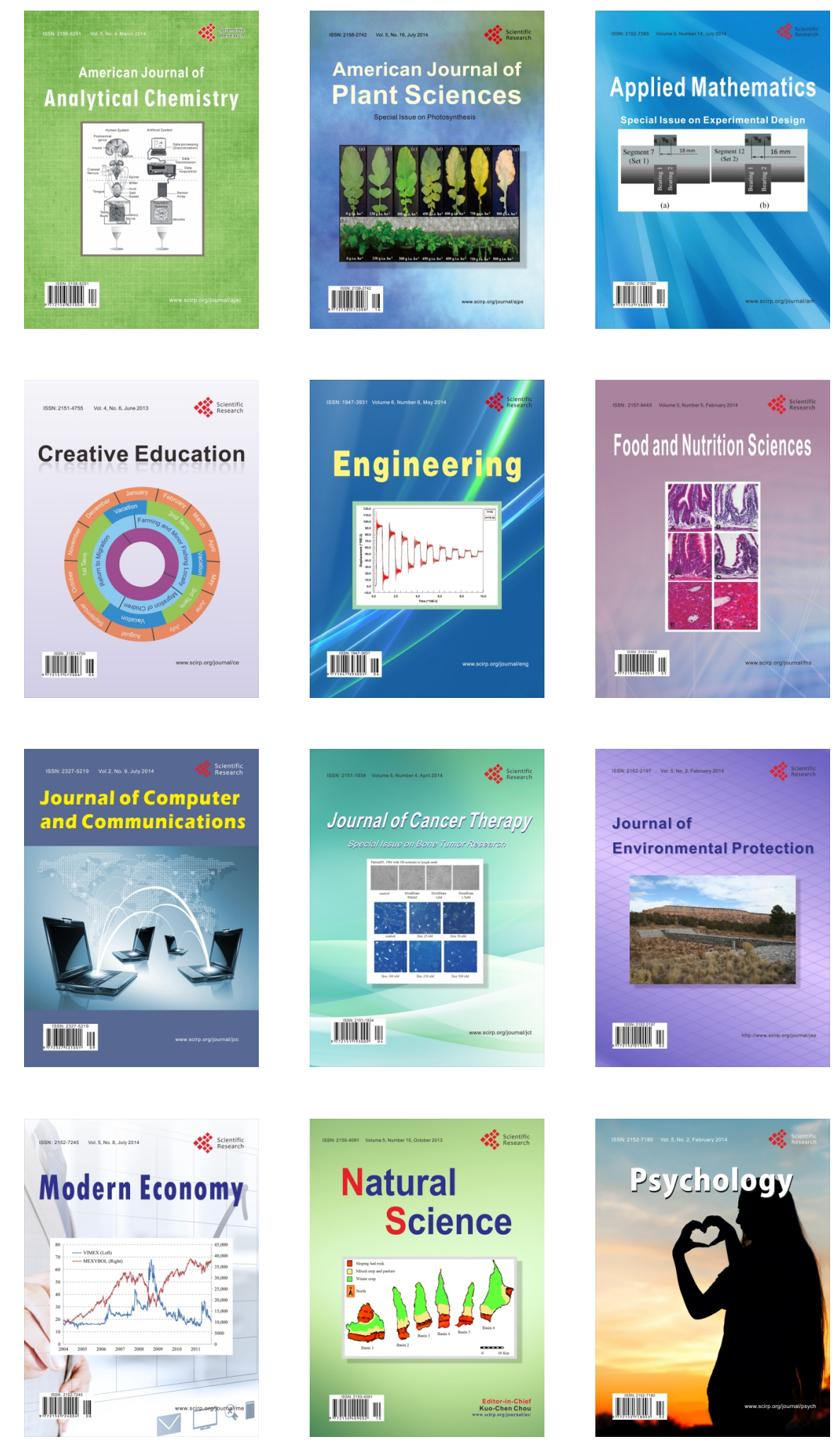